\title{
'Stump appendicitis': postappendectomy appendicitis
}

\author{
Sanoop Koshy Zachariah
}

Department of General, Gastrointestinal \& Laparoscopic Surgery, MOSC Medical College, Cochin, Kerala, India

\section{Correspondence to} Professor Sanoop Koshy Zachariah;

skzach@yahoo.com

Accepted 28 November 2014

\section{DESCRIPTION}

A 58-year-old woman presented with acute abdominal pain and vomiting of 3 days duration. She had undergone laparotomy for appendicular perforation 25 years earlier. She had recurrent episodes of abdominal pain for the past 5 years and was being treated as a case of adhesive intestinal colic. Clinical examination revealed a distended and tender abdomen with an infra umbilical midline scar and maximal tenderness in the right iliac fossa associated with guarding and rigidity. Her pulse rate was $110 / \mathrm{min}$; blood pressure $110 / 60 \mathrm{~mm} \mathrm{Hg}$ and temperature was $100^{\circ} \mathrm{F}$. Total white cell count was $18400 \mathrm{~mm}^{3}$ (85\% neutrophils). Urine analysis was unremarkable. Ultrasonography showed interloop fluid and dilated bowel loops in the right iliac fossa. Abdominal CT scan showed features of an inflammatory mass in the right iliac fossa with pericaecal fat stranding, a thickened caecal wall, dilated small bowel loops and fluid. Diagnostic laparoscopy revealed purulent peritoneal fluid, dense adhesions between omentum and laparotomy scar along with an inflammatory mass in the right iliac fossa. Laparoscopic dissection was difficult; hence the procedure was converted to a laparotomy. After meticulous dissection, the bowel loops were separated. The distal ileum adherent to the caecal wall was meticulously separated to reveal a small residual appendicular stump that was oedematous, inflamed and about $2 \mathrm{~cm}$ long (figure 1). The stump was excised after transfixing the base close to the caecal wall (figure 2). The postoperative period was uneventful. Histopathological report was confirmatory of appendicitis. The patient has been on regular follow-up for 1 year and is asymptomatic.

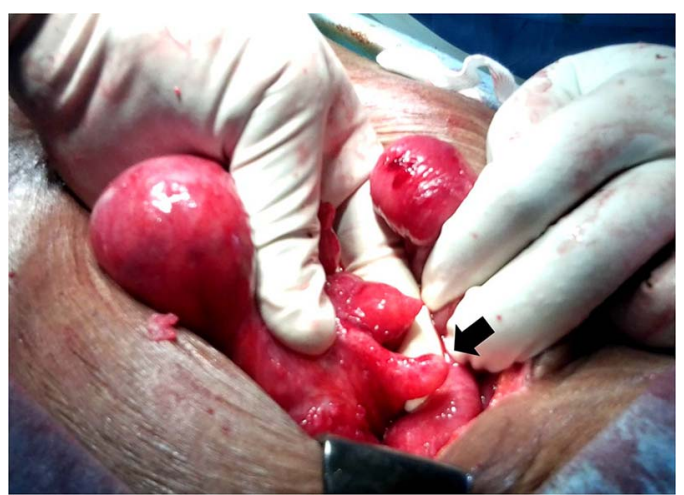

Figure 1 The residual inflamed stump of the appendix is clearly seen (arrow) after separation of the adherent small bowel.

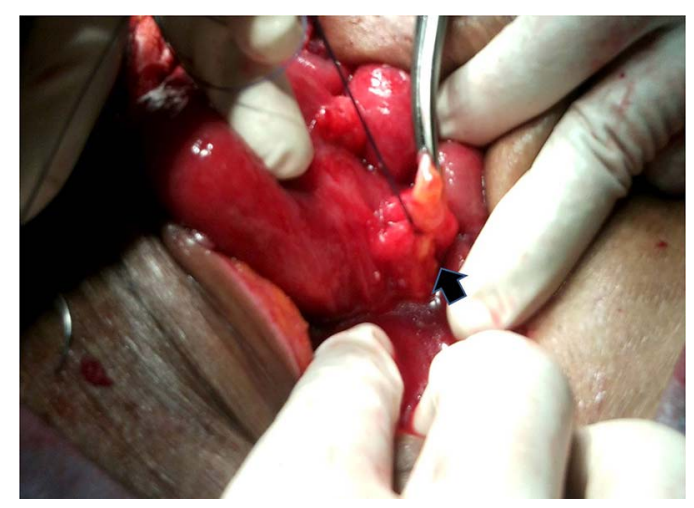

Figure 2 The stump is transfixed at the base, almost flush with the caecal wall prior to excision.

\section{Learning points}

- Stump appendicitis (SA) is a rare but potentially serious complication of appendectomy, with reported incidence of 1 in 50000 cases. However, an increasing number of cases are being reported in the literature. ${ }^{12}$

- SA should be considered in the differential diagnosis of patients presenting with recurrent abdominal or right iliac fossa pain even with a history of previous appendectomy (laparoscopic or open).

- An appendicular stump smaller than $3 \mathrm{~mm}$ might help reduce $\mathrm{SA}$. Completion appendectomy is the treatment of choice. Conservative management with antibiotics has been shown to be effective in treating SA. ${ }^{3}$

- More research is needed to identify strategies to prevent SA.

Acknowledgements The author would like to thank the MOSC medical college administration for the encouragement given in publishing this article.

Competing interests None.

Patient consent Obtained.

Provenance and peer review Not commissioned; externally peer reviewed.

\section{REFERENCES}

1 Kumar A, Sharma A, Khullar R, et al. Stump appendicitis: a rare clinical entity. J Minim Access Surg 2013:173-6.

2 Crocco S, Pederiva F, Zanelli E, et al. Stump appendicitis seven years after appendectomy. APSP J Case Rep 2013;4:33.

3 Hashmi KS, Wibberley H, Ahmed I, et al. Stump appendicitis: a relatively under-reported reality. BMJ Case Rep. Published: 17 Sep 2017. doi:10.1136/bcr-2012-008449
To cite: Zachariah SK. BMJ Case Rep Published online: [please include Day Month Year] doi:10.1136/bcr-2014208544 
Copyright 2014 BMJ Publishing Group. All rights reserved. For permission to reuse any of this content visit http://group.bmj.com/group/rights-licensing/permissions.

BMJ Case Report Fellows may re-use this article for personal use and teaching without any further permission.

Become a Fellow of BMJ Case Reports today and you can:

- Submit as many cases as you like

- Enjoy fast sympathetic peer review and rapid publication of accepted articles

- Access all the published articles

- Re-use any of the published material for personal use and teaching without further permission

For information on Institutional Fellowships contact consortiasales@bmjgroup.com

Visit casereports.bmj.com for more articles like this and to become a Fellow 